\title{
SUCCESSION FOLLOWING THE 1974 WATERFALLS CANYON Fire
}

\author{
KATHLEEN M. DOYLE $\bullet$ DENNIS H. KNIGHT \\ DEPARTMENT OF BOTANY UNIVERSITY OF WYOMING \\ LARAMIE
}

\section{$\checkmark \quad$ INTRODUCTION}

A major objective of the National Park Service is to preserve examples of natural features and processes that characterize the North American landscape. Fire is now widely recognized as a natural process in many ecosystems, but its management remains a controversial issue. Research on successional change following fire will contribute to improved fire interpretation and management.

The Waterfalls Canyon (WC) fire was started by lightning in July 1974 and continued burning until December. Approximately 1414 ha were burned on the west side of Jackson Lake in Grand Teton National Park (GTNP) (Barmore et al. 1976). This fire was especially significant because it was one of the first large fires to occur in a National Park following the adoption of the revised fire management policies in 1972, allowing natural fires to burn in certain designated areas. Prior to 1972 , the longstanding fire management policy was to suppress both natural and human-caused fires (Barmore et al. 1976).

Considerable scientific and public interest was generated by the Waterfalls Canyon fire. For example, tourists in GTNP complained about the smoke which obscured views of the Tetons. For park scientists, the Waterfalls Canyon fire provided an opportunity to initiate studies to better understand and interpret the fundamental role of fire in GTNP.
During the summer of 1975 , Barmore et al. (1976) established a series of permanent plots to evaluate post-fire changes in vegetation and small mammal and bird abundance. In addition, baseline data were collected in 1975 describing the soils, streamwater chemistry, and insect populations. Permanent plots were established within two stands that burned in 1974: 1) a severely burned stand (forest floor burned exposing mineral soil), and 2) a moderately burned stand (forest floor mostly unburned). In addition, permanent plots were established in two adjacent sites, both unburned in 1974 , but which appeared to be very similar to the WC burned area. One was a mature spruce-fir forest that had not burned for more than 100 years, and the other was a stand that burned in 1932 .

Important data was collected by Park scientists following the Waterfalls Canyon fire, with vegetation, bird and mammal data being collected in the four study sites in 1975, 1976, 1977 and 1983.

\section{$\downarrow \quad$ OBJECTIVES}

The primary objective of our research is to better understand successional dynamics following fire in GTNP and to refine methods with which to monitor and assess patterns of successional change following fire. Our research focuses on the Waterfalls Canyon fire. In addition, over the course of the three-year project, we will synthesize information on all known fires in GTNP, thereby 
determining how well the information collected for the Waterfalls Canyon fire can be extrapolated to other areas within and surrounding the Park.

We will resample the permanent plots for plant, bird and small mammal abundance using the methods adopted by Barmore et al. (1976), and determine trends and rates of change by comparing 1991/1992 data to comparable data collected in 1975, 1976, 1977 and 1983. We will use these data to test or refine models about coniferous forest succession.

We will examine spatial and topographic effects on post-fire plant succession within the burn using GIS methods. Because succession is spatially variable, succession cannot be effectively studied through monitoring a small number of permanent plots. To overcome the shortcomings of permanent plot studies, we will collect and compare data from a series of plots within the WC burned perimeter which represent a range of environmental conditions. We will measure variables such as slope, distance from unburned forest, the nature of the surrounding vegetation, and characteristics of the substrate; and we will evaluate the effect of these variables on postfire changes in vegetation.

We will compare the results obtained from the Waterfalls Canyon fire to observations made on other forest fires in GTNP, with the goal of determining how widely the Waterfalls Canyon fire results can be extrapolated.

\section{STUDY AREA}

The Waterfalls Canyon burn extends along the west side of Jackson Lake for about $10.8 \mathrm{~km}$ and has a maximum width of approximately $2.6 \mathrm{~km}$. Elevation ranges from $2,065 \mathrm{~m}$ on the lake shore to about $2,898 \mathrm{~m}$ on the east side of Ranger Peak. Slopes range from approximately 0 to $40 \%$. Three major canyons bisect the study area, contributing to the variation in environmental conditions. There is considerable variation in vegetation within the study area. Engelmann spruce (Picea engelmanii), subalpine fir (Abies lasiocarpa), and lodgepole pine (Pinus contorta) are the most abundant conifers, while whitebark pine (Pinus albicaulis) occurs locally at higher elevations. Aspen (Populus tremuloides) and Douglas fir (Psuedotsuga menziessii) are abundant in the northern half of the burn. Wet and dry meadows are scattered throughout the area. In $1974,89 \%$ of the area within the perimeter of the burn was subjected to flames of varying intensity.

\section{PROGRESS TO DATE}

Vegetation was resampled on all permanent plots. As our field season started in July, and previous bird and small mammal data were collected earlier in the summer, for consistency we postponed resampling birds and small mammals until 1992. All available data, from 1975, 1976, 1977, 1983 and 1991, are now being entered into computer files and will be summarized within the next few months.

A reconnaissance survey within the Waterfalls Canyon Study Area was accomplished. Aerial photographs, maps of fire intensity (completed in 1975) and topographic maps were used, in conjunction with site visits, to determine the range of variation. Information collected regarding the variability of the study area is currently aiding our efforts to design methods to quantify and analyze the spatial variability of post-fire vegetation change following fire within the entire study area.

Sites within or adjacent to GTNP which have burned within the last 7 years were visited. These include the Beaver Creek fire, the Hunter Fire, the Mystic Isle Fire, the Dave Adams Hill Fire and the Huck Fire. Notes on the similarity and differences between these fires and the Waterfall Canyon Fire were recorded. This information will help in determining the extent to which successional patterns in Waterfalls Canyon are representative of the Park as a whole.

In sum, field work and data analysis are on schedule. Data collection will continue during the summers of 1992 and 1993.

\section{- Literature CiTED}

Barmore, W. J., D. L. Taylor, and P. Hayden. 1976. Ecological effects and biotic succession following the 1974 Waterfalls Canyon fire in Grand Teton National Park. Unpublished report, GTNP. 